\title{
THE ROLE OF COMMUNICATION AS THE DRIVE FOR IMMIGRATION: A CASE STUDY IN FINLAND
}

\author{
Zahra Hosseini, \& Sirkku Kotilainen \\ Information Technology and Communication, Tampere University (Finland)
}

\begin{abstract}
Recently many studies have remarked migration issues. Thus, in countries such as Finland, having a governmental strategy for increasing the number of migrants, especially educated immigrants or encouraging international students to stay, is highly important. While Finland is recognized as the happiest country, it would be arguable why it is not included in the list of top destination countries for immigration. The literature shows communication is one of the most issues for immigrants and international students, particularly those from Asian countries. Therefore, this study aims to understand how technology-based communication such as the use of social media influences international students' decision to immigrate. Respectively, 23 Iranian tertiary-level students were interviewed as the case of the study. Uses and Gratification theory was employed to investigate the role of media usage among the participants. The findings showed that although there is high desire among the participants to immigrate to Finland, the difficulty and unpopularity of the Finnish language and culture of distance in Finland reduces the motivation to emigrate and made the participants feel being the outsider in the university and society. The use of communication media has facilitated university admissions and communication with family, friends, compatriots and other international students, but has not been able to connect them to Finnish society. While educated immigrants in every country are human resources, the results of this study draw our attention to explore different aspects of communication, identifying motivating factors and reducing frustration among international students for immigration. These results emphasize on the development of strategies and tools for harnessing the potential of media and technology to connect international students as future educated immigrants in the host community.
\end{abstract}

Keywords: Communication, international students, Finnish culture, media, immigration.

\section{Introduction}

Globalization has modified the way that people become aware of different opportunities particularly for working and studying around the world. With the growth of the number of international students abroad, the number is expected to hit 8 million by 2025 (ICEF, 2017). Typically, International students in Europe usually experience the new lifestyle that may decrease their intentions to return their home countries. These aspects may relate to religion, violence, inequality, corruption, poverty (Stanojoska \& Blagoce, 2012). QS World University Ranking (2018) published four top destination countries including the United State, the United Kingdom, France, Australia attracts foreign students to their universities. While the World Happiness Report (2021) has introduced Finland as the happiest country in the world, it would be arguable why it is not included in the list of top destination countries for immigration.

On the other hand, assistance of communication technology has provided the opportunity for online admission and registration in institutes and universities from the home countries and caused an increase in the number of international students (Stevenson 2009; Thulin \& Vilhelmson, 2013). People may become familiar with laws and rules of other countries via internet before any decision for emigration and after migration; they receive information from the different digital portals and media, which effects on their decisions for immigration. Several studies acknowledged the role of social media aiding international students to communicate with each other (Saw et al., 2013; Hamid et al., 2016) and even when it was not shown beneficial for academic achievement, it still helped the participant with their host culture acculturation (Yu et al., 2019).

In this regard, this study utilizes Uses and Gratifications Theory (UGT) to recognize how technology-driven communication such as social media usage affects international students' decision for immigration in Finland. UGT has a root in communication perspective that deals with the effect of 
audience's motivation and their media-consuming activities. Some studies utilized UGT for studying the dual role of the internet and social media for cultural adaptation and resulted differently. For instance, Wang and Sun (2009) believe having the poor cultural adaptation and feeling loneliness of immigrants in the host country enhance their social media usage, while, Yang (2018) argues that Chinese international students used social media for being better acculturated into the host society. In this study, UGT opens ways to understand role of media regarding communication challenge in the case study.

\section{Methods}

By considering the Iranian nationality of the main researcher, Iranian students in Finland were selected as the case for this study $(\mathrm{N}=23$, data collected in 2017). The study employed the snowball sampling method to participate 23 Iranian tertiary-level students. A semi-structured interview protocol uncovered the interviewees' values, feelings, beliefs, and experiences of the phenomenon. The participants were interviewed face-to-face or online based on their location. The data were collected through audio recordings and transcribed verbatim for analysis of the meanings, especially those between the sets of categories. Thematic analysis was employed to identify, analyze, and reporting following Braun and Clarke's (2014) guide. In this respect, the transcribed data was coded and categorized at the next step, themes were defined based on UGT and accordingly patterns were determined. The researchers considered and followed the ethical principles of research with human participants and ethical reviewing the human sciences in Finland (TENK, 2019).

\section{Finding}

\subsection{Communication issues}

The finding demonstrated although most participants (18 of 23) had positive intentions to immigrate to Finland, however, they had discomforted experiences in communication which affected their decision for immigration. In their opinion, Finnish culture and language reduce the opportunities to find a suitable career and increase level of unpleasant feeling about cold and darkness.

Finnish culture seems unwelcoming for immigrants because; a) communication avoidance: the participants described Finnish culture as a culture with limited verbal and nonverbal communication with foreigners. Most participants experienced the Finnish lifestyle as individualist and many of them believed that there is a huge distinction between Finnish people and them. A young student yielded his disappointment: "What I am missing here is the people whom I can talk with." Some participants stated that Finnish students hesitated participating in student's assignment groups. A few participants believed that Finnish students avoid participating in study activities more with students from non-EU countries. b) silence, distance, and privacy in Finnish culture although were respected by the participants, only two of 23 participants felt comfortable with them, and others were struggling with communication issue and feeling outsiders in Finnish society.

Based on the findings, most of the participants had chosen Finland for studying because of available English education for tertiary-level many participants believed Finland. They believed living in Finland is easier for English speakers among non-English countries in Europe. Most participants had attended at least one course to learn Finnish but were not motivated to continue. Three participants stated that they did not want to learn Finnish. Some participants regretted choosing to immigrate to Finland when they felt they had to learn Finnish to find a job. The main reasons for discouragement were: 1) Learning Finnish is difficult and time consuming. 2) Finnish is not popular and "it is a language spoken by only 5 million people" (participant 18) and, 3) life and particularly professional activities can progress in Finland even with the limited Finnish skills. "Many people here speak the English language. They know English, it helps us to reduce misunderstandings" (participant 23 said).

\subsection{Media, as a drive}

Based on UGT the role of media, particularly social media as a drive for migration and immigration is demonstrated in the following aspects:

3.2.1. Source of information for migration. Most of the participants used some forums and social media to gain information about Finland before migration. For all participants the process of admission was online and online services and social media helped their settlement in Finland. It seems communication technology has a positive role in the first steps of migration by providing information and facilitating official communication with distance. 
3.2.2. Communication support, Participants utilized the different applications of social media to connect to their friends and family in Iran more than in Finnish society. They contacted their families at least once a week. Most participants were always available to their families in virtual groups or individually.

3.2.3. Source of news. The participants were members of groups or channels in social media to receive news. a) News about Iran via online TV, Facebook, or Telegram channels, b) University news, via newsletter email, Facebook pages, and Student Union website, c) Events in Finland mostly via Facebook pages.

3.2.4. University tasks. Formal communication with other international or Finnish students was usually done through Facebook, the student union, and the newsletter pages in the emails. "In the case of student events, we receive them from our Facebook groups. To attend the event with friends, we are informed in our private group, the content of the lessons is also in the Moodle" (Participant 13 said).

3.2.5. Sharing. All participants were Facebook members, and they asked questions from students or other compatriots, but they were reluctant to share content. "Facebook wastes my time. I read but do not post much although I am a member of many pages" (participant 17 said). Participant 7 used Facebook and YouTube to get the news, but had a negative attitude towards most social media, believing that these platforms are managed by powerful people or organizations that manipulate people's minds and give them biased information. He used the media, but believed that he had to analyze everything before believing the content. Two students were the passive members in Finnish forums and groups.

\section{Discussion}

The results of the study demonstrated the efforts of international students in communication with Finnish society and insufficient role of media in reducing this struggle. While Finland itself is in the list of brain drain countries (Mahroum, 2005), the strategy of Finland for accepting educated immigrants is planned, Finland is not the first destination for international students due to its geographical location.

Whereas, the quality of its education system is known all over the world, which creates international interest (Balbutskaya, 2015) adopting a new strategy to reduce the challenge for immigration seems essential. Despite the help of technology to facilitate communication, Finnish language learning difficulty appears to be a serious barrier for cultural integration, especially for job seekers in Finland (Bontenbal \& Lillie, 2019). This study highlighted the communication challenge as a pushing factor for foreigners living in Finland. Also, showed the communication challenge as stressors for foreigners in Finland. Croucher et al (2013) explain that Finland is not a country for immigrants and Finnish history influences the way Finnish people treat foreigners. The researchers assert that Finns moved to Sweden to work before the 1970s, and most immigrants to Finland during the 1980s were those who had left the country in the past decades. The immigrants who had been living abroad in Finland since the 1990s. They were usually from Russia and Estonia (Korkiasaari \& Soderling, 2003).

Indeed, many participants in the study felt that Finns would not accept non-EU friendships. Likewise, Jaakkola (2005) argues that Finn feel more comfortable communicating with foreigners who are more culturally and economically like the Nordic countries than with foreigners who came from a lower standard of living countries. The survey in 1993-2003 indicated that Finns have a more positive attitude towards immigrants living in Finland than in the past, especially in the case of educated immigrants who have higher-level jobs as doctors, teachers and assistants, social employment agency and police officials. However, they prefer migrants to be hired as cleaners and taxi drivers (Jaakkola 2005). This negative attitude is more relevant to refugees and Muslims than educated students (Jaakkola 2005; Säävälä 2008).

Ryabina (2008) states Finnish culture has its specific characteristic aspects of communication as other culture. It is individualistic and low-context communication. These characteristics distinguish Finnish culture from other cultures even in Europe. That claim is in line with the finding of this study that many participants described silence as the characters in Finnish culture which is a barrier to communication. Differences in communication behavioral styles seem to have been an obstacle to the cultural integration of international students.

As an important aspect of communication, language can always act as a barrier to the communication of immigrants in the host country (Adsera \& Pytlikova 2015; Yao 2016). The Finnish Language has reported the issue in education (Sinkkonen \& Kyttälä, 2014) and business (Grinblatt \& Keloharju 2000). Learning Finnish academic language takes four to eight years (Hakuta, Butler \& Witt 2000). Although most of the interviewed students had passed a few Finnish language courses, most of 
them were not confident to speak or even understand Finnish. However, the participants did not need to learn the Finnish language because they felt Finns are not interested to communicate with them even if they were competent to communicate in English language. Lack of local language proficiency and communication acted as a dual failure to keep the international students as outsiders.

Although Communication technology is developed in Finland and all students have access to the internet facilities in the university, home, and other places, it did not show a remarkable positive role in connecting international students to locals. This result is in line with the findings of Wang and Sun (2009) and Yang (2018) adopting the Use and Gratification Theory to explain the role of social media among immigrants to deal with their acculturation in the host society. The result of this study demonstrated that communication technology was used for personal communication more than creating a network in institutional settings (Sleeman et al, 2020; Hosseini et al, 2020).

Graduated people are always the human resource for every country; however, Europe seems to accept low-skilled immigrants easier (Berger, 2019). In recent years, official governments-organized integration training programs have been investing to help immigrants to learn the language, find a job and integrate into Finnish society. In addition, Civil Society Organizations in Finland (CSO), which is established by native Finn, is offering support to immigrants (Bontenbal \& Lillie 2019). These services seem more beneficial for helping unskilled immigrants than educated ones, and there have been fewer efforts to motivate graduated international students for immigration in Finland.

\section{Conclusion}

Regarding the Uses and Gratification Theory, the finding of the study indicated that despite the increasing use of social media in everyday life to obtain information or connect with international students, it does not help them communicate much with the Finnish people. Perhaps because social media and current portals such as Facebook and reduction of their trustworthiness among educated people do not specialize in filling the cultural gap between locals and immigrants. In this regard, the findings recommend the strengthening of communication portals, which provide reliable and unbiased information about immigrants' relations with the host country.

On the other hand, while many language courses, programs, and sites try to develop the language skills of immigrants, it still seems challenging because international students need to be more motivated to learn and use language to communicate with Finns in informal setting. Currently, the international student's study and deal with their basic needs in Finland in English. They communicate only with their competitors and students of other nationalities through the media. Media is a bridge to connect them to their own country relative to the host country. Respecting UGT, social media has failed to facilitate communication between the foreigners and locals in Finland.

The results of this study draw attention to the use of maximum technology potential in Finnish society. There is a need to adopt strategies for the participation of international students and graduated in Finnish society to increase their cultural integration. Regarding the importance of the context in communication, more studies are recommended in design and practice media to utilize the potential of communication technology and media to help migrants and enhance their cultural adaptation in different contexts. Moreover, the current Covid 19 crisis around the world makes communication technology and media more important than ever for succeeding in any country.

\section{References}

Adsera, A., \& Pytlikova, M. (2015). The role of language in shaping international migration. The Economic Journal, 125(586), F49-F81. https://doi.org/10.1111/ecoj.12231

Balbutskaya, E. (2015), Demand for Finnish Education Export in Russia. Case: Saimaa University of Applied Sciences master thesis. http://urn.fi/URN:NBN:fi:amk-201505117205

Berger, A. (2019). EU justice and home affairs: towards an inclusive research agenda? Journal of European Integration, 41(4), 563-568. https://doi.org/10.1080/07036337.2019.1647003

Bontenbal, I., \& Lillie, N. (2019). The Role of the Third Sector in the Labour Market Integration of Migrants, Refugees and Asylum Seekers in Finland. URL: https://www.jyu.fi/hytk/fi/laitokset/yfi/en/staff/bontenbal-ilona/finland-report-final-4-102019.pdf

Braun, V., \& Clarke, V. (2006). Using thematic analysis in psychology. Qualitative research in psychology. Qualitative Research in Psychology, 3(2), 77-101.DOI: 10.1191/1478088706qp063oa

Croucher, S.M. (2008). Looking beyond the hijab. Cresskill, NJ: Hampton Press. 
Grinblatt, M., \& Keloharju, M. (2000). Distance, language, and culture bias: The role of investor sophistication. Helsinki School of Economics and Business Administration Department of Accounting and Finance. http://dx.doi.org/10.2139/ssrn.222169

Hakuta, K., G. Y. Butler, and D. Witt. (2000). How Long does it take English Learners to Attain Proficiency? Policy Report 2000-1. Irvine, CA: University of California, Linguistic Minority Research Institute. URL: https://eric.ed.gov/?ID=ED443275

Hamid, S., Bukhari, S., Ravana, S. D., Norman, A. A., \& Ijab, M. T. (2016). Role of social media in information-seeking behaviour of international students. Aslib Journal of Information Management. https://doi.org/10.1108/AJIM-03-2016-0031

Hosseini, Z., Kotilainen, S., \& Okkonen, J. (2020, February). The Potential of Social Media to Enhance Cultural Adaptation: A Study on Iranian Students in the Finnish Context. In International Conference on Information Technology \& Systems (pp. 535-549). Springer, Cham. http://urn.fi/URN:NBN:fi:tuni-202003242843

ICEF (2017). OECD charts a slowing of international mobility growth. Revised on 17 July 2020: https://monitor.icef.com/2017/09/oecd-charts-slowing-international-mobility-growth/

Jaakkola, M. (2005) The Attitudes of Finns towards Immigrants in 1987-2003. Labour Policy Studies 286. Ministry of Labour, Helsinki.

Korkiasaari, J., \& Söderling, I. (2003). Finnish emigration and immigration after World War II. Turku: Siirtolaisuusinstituutti.

Mahroum, S (2005). The international policies of brain gain: a review. Technology Analysis \& Strategic Management, 17 (2), pp 219-230. https://doi.org/10.1080/09537320500088906

Neyer, A. K. \& Harzing, A. W (2008). The Impact of Culture on Interactions: Five Lessons Learned from the European Commission. European Management Journal, 26(5), 325-334. https://doi.org/10.1016/j.emj.2008.05.005

QS World University Ranking (2018) revised on 12 July 2020. URL: https:/www.qs.com/4-countriesattract-international-students/

Ryabina, E. (2008). Comparison of Udmurt, Estonian, and Finnish dialogues: Characteristics of communicative behaviour. Trames, 12(1), 40-50. DOI: 10.3176/tr.2008.1.03

Säävälä, M. (2008). How do locals in Finland identify resident foreigners. Finnish Yearbook of Population Research, 115-130. DOI: https://doi.org/10.23979/fypr.45037

Saw, G., Abbott, W., Donaghey, J., \& McDonald, C. (2013). Social media for international students-it's not all about Facebook. Library Management https://doi.org/10.1108/01435121311310860

Sinkkonen, H. M., \& Kyttälä, M. (2014). Experiences of Finnish teachers working with immigrant students. European Journal of Special Needs Education, 29(2), 167-183. https://doi.org/10.1080/08856257.2014.891719

Sleeman, J., Lang, C., \& Dakich, E. (2020). Social media, learning and connections for international students: The disconnect between what students use and the tools learning management systems offer. Australasian Journal of Educational Technology, 36(4), 44-56. https://doi.org/10.14742/ajet.4384

Stanojoska, A, \& Blagoce, P. (2012), Theory of push and pull factors: A new way of explaining the old. In Book of the International Scientific Conference (pp. 179-194). Belgrade, Serbia. URL: https://nsar.org.rs/sites/default/files/docs/Rajs2012-Tom1.pdf

Stevenson B., (2009). The Internet and Job Search. In Autor DH. (ed.) Studies of Labour Market Intermediation, 67 - 86. National Bureau of Economic Research, Cambridge, MA. URL: https://www.nber.org/papers/w13886

TENK (2019). Retrieved on 2021/01/25. URLÖ https://tenk.fi/sites/default/files/202101/Ethical_review_in_human_sciences_2020.pdf

Thulin E and Vilhelmson B., (2013). Virtual practices and migration plans: a qualitative study of urban young adults. Population, Space and Place. https://doi.org/10.1002/psp.1766

Wang, Y., \& Sun, S. (2009). Examining Chinese students' Internet use and cross-cultural adaptation: Does loneliness speak much? Asian Journal of Communication, 19(1), 80-96. https://doi.org/10.1080/01292980802618494

World Happiness Report (2020). Revised on 12 April 2021: URL https://worldhappiness.report/

Yang, C. (2018). US-based social media use and American life: A study of Chinese students' acculturation and adaptation in America. Global Media and China, 3(2), 75-91. https://doi.org/10.1177/2059436418783765

Yao, C. W. (2016). Unfulfilled expectations: Influence of Chinese international students' roommate relationships on sense of belonging. Journal of International Students, 6(3), 762-778.

Yu, Q., Foroudi, P., \& Gupta, S. (2019). Far apart yet close by: Social media and acculturation among international students in the UK. Technological Forecasting and Social Change, 145, 493- 502. https://doi.org/10.1016/j.techfore.2018.09.026 